\section{OMII}

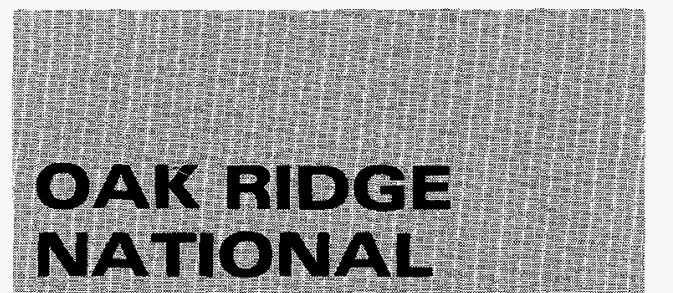

LABORATORY

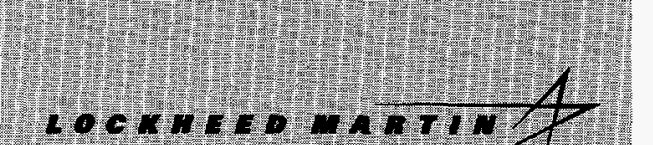

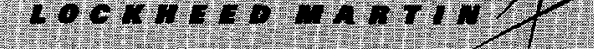
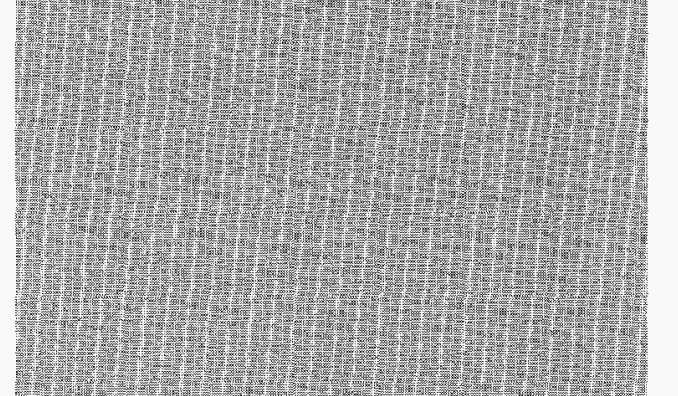

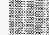

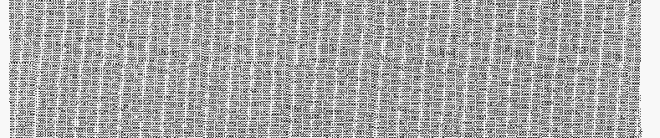

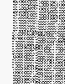

新部

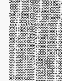

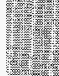
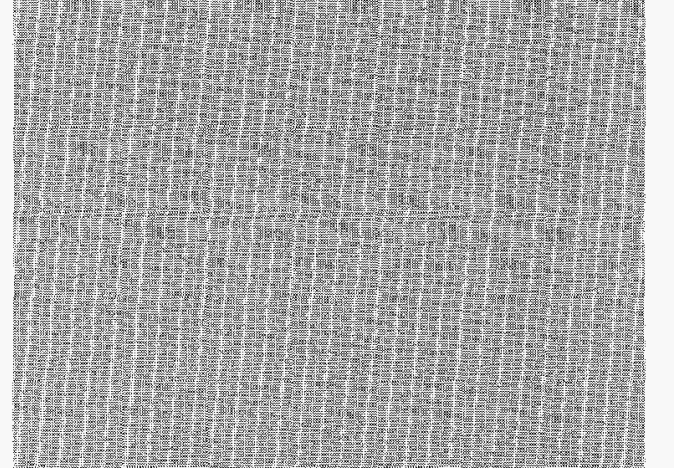

\section{Strategies for the Cost-Effective Treatment of Oak Ridge Legacy Wastes}

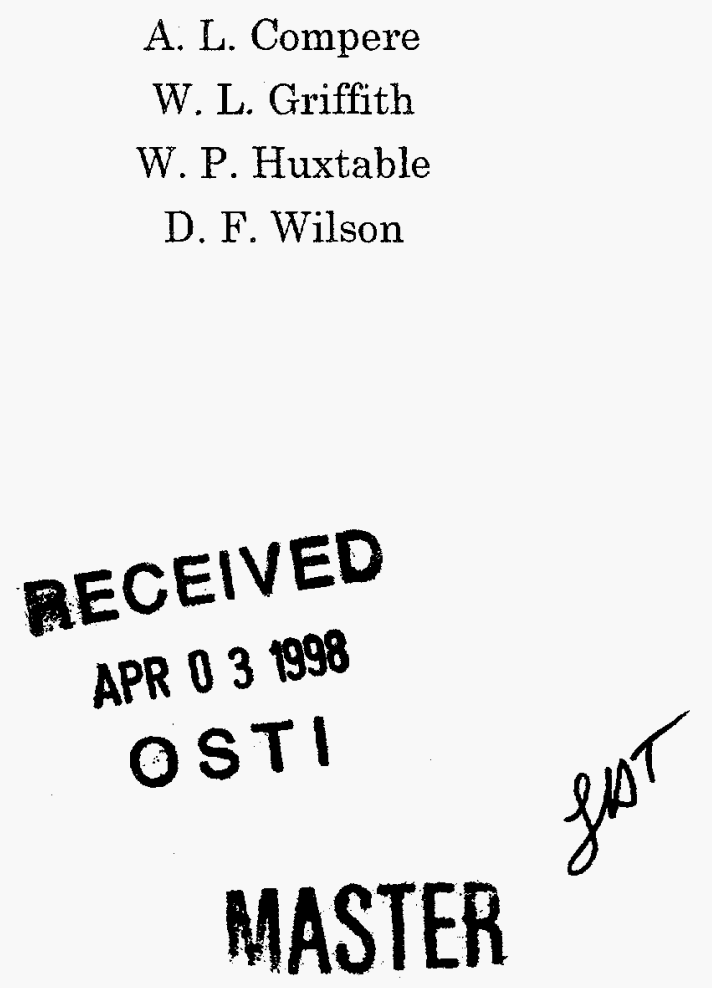

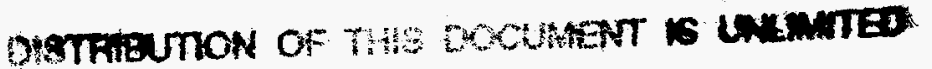


This report has been reproduced directly from the best available copy.

Available to DOE and DOE contractors from the Office of Scientific and Technical Information, P.O. Box 62, Oak Ridge, TN 37831; prices available from (423) 576-8401 FTS $626-8401$.

Available to the public from the National Technical Information Service, U.S. Department of Commerce, 5285 Port Royal Rd., Springfield, VA 22161.

This report was prepared as an account of work sponsored by an agency of the United States Government. Neither the United States Government nor any agency thereof, nor any of their employees, makes any warranty, express or implied, or assumes any legal liability or responsibility for the accuracy, completeness, or usefulness of any information, apparatus, product, or process disclosed or represents that its use would not infringe privately owned rights. Reference herein to any specific commercial product, process, or service by trade name, trademark, manufacturer, or otherwise, does not necessarily constitute or imply its endorsement, recommendation, or favoring by the United States Government or any agency thereof. The views and opinions of authors expressed herein do not necessarily state or reflect those of the United States Government or any agency thereof. 


\section{DISCLAIMER}

Portions of this document may be illegible in electronic image products. Images are produced from the best available original document. 
ORNL/TM-13577

\title{
Strategies for the Cost-Effective Treatment of Oak Ridge Legacy Wastes
}

\author{
A. L. Compere \\ W. L. Griffith \\ W. P. Huxtable \\ D. F. Wilson \\ Prepared by the Oak Ridge National Laboratory \\ Oak Ridge, Tennessee 37831 \\ managed by \\ Lockheed Martin Energy Research \\ for the \\ U. S. Department of Energy \\ under Contract No. DE-AC05-96OR22464
}

Date Published: March 1998 



\section{Contents}

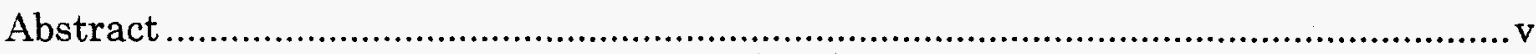

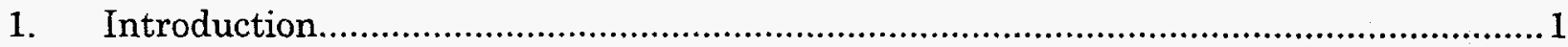

2. Volumetrically-contaminated nickel scrap..........................................................

3. Combined processing of aluminum compressor blades and alkali metal fluorides .......5

4. Removal of mercury from lithium processing equipment........................................ 7

5. Fixed-film biodenitrification of low-concentration, low-dissolved-solids Y-12 Plant

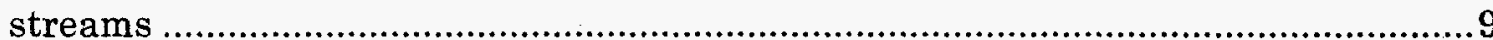

6. Development of a complete-recycle scrubbing process for lithium chloride electrolysis offgas ..................................................................................................... 11

7. Maximizing recycle of nitrates from extraction raffinates ...................................... 13

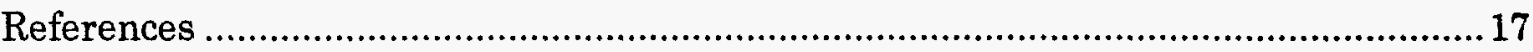




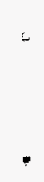




\title{
Strategies for the Cost-Effective Treatment of Oak Ridge Legacy Wastes
}

\author{
A. L. Compere \\ W. L. Griffith \\ W. P. Huxtable \\ D. F. Wilson
}

\begin{abstract}
Research and development treatment strategies for treatment or elimination of several Oak Ridge plant liquid, solid, and legacy wastes are detailed in this report. Treatment strategies for volumetrically contaminated nickel; enriched uraniumcontaminated alkali metal fluorides; uranium-contaminated aluminum compressor blades; large, mercury-contaminated lithium isotope separations equipment; lithium process chlorine gas streams; high-concentration aluminum nitrate wastes, and highvolume, low-level nitrate wastes are discussed. Research needed to support engineering development of treatment processes is detailed.
\end{abstract}




\section{Introduction}

Our working groups have, for more than a decade, focused on improvements to Oak Ridge production facilities which either reduced generation of process waste or eliminated legacy wastes. Many of these wastes have remained for decades and historically-proposed treatment methods have often been either too expensive or unable to meet current environmental or safety requirements. In our experience, improvements in technology or advances in chemical and metallurgical process technologies have provided a basis for the development of novel, cost-effective waste treatment technologies.

Because chemical process and waste treatment technologies, as well as process chemical simulations, are continually improving, our groups regularly discuss and evaluate the potential of new technologies or approaches to resolve have periodic discussions to resolve long-standing process and legacy waste treatment issues. The focus is on finding simple, cost-effective strategies for treating high-volume wastes. Because bench research and simulations are typically required to develop, optimize, or re-optimize a process, we prepare a short document describing the opportunities and process development costs to permit facilities managers to evaluate potential use of new technologies in exisiting operations (e. g., Huxtable and coworkers 1993).

If we are successful in obtaining funding and permission to proceed, we typically perform a detailed literature survey; develop bench-scale systems which model the expected process, fill in any areas where necessary data is unavailable, optimize the process to meet new requirements using both model systems and simulators, pilot the process, develop procedures, and help train the process operating staff. Where possible, we optimize to provide the desired process parameters within existing equipment or find appropriate unused equipment within the Oak Ridge complex.

In previous years, this approach has been successful in developing and implementing processes which essentially eliminated the largest single Y-12 Plant solid waste, a uranium-contaminated denitrification sludge, and the largest single Y-12 Plant chemical process waste, raffinate from aluminum nitrate crystallization. Both process reoptimizations are simple in operation, use existing equipment, and have lower operating costs. Across a seven year period, the net operation and capital equipment savings from these two process modifications exceeded $\$ 15$ million, approximately a hundred-fold return on investment. Both processes were honored with a variety of internal and Oak Ridge Operations Office awards, including annual waste minimization awards.

New technologies appear likely to provide simple, cost-effective, operations for reducing or eliminating several high-volume legacy metal wastes, such as nickel, aluminum alloys, alkali metal fluorides, and mercury-contaminated residues from the lithium isotope separation processes.

Because of the scale of operations, the amounts of legacy metal wastes from gaseous diffusion operations is often very large. The Paducah Gaseous Diffusion Plant currently stores 6,000 tons of $>99 \%$ pure nickel ingot volumetrically contaminated with uranium and technetium. Although a number of different approaches for decontaminating and recycling this material have been proposed, none has been successfully implemented. Based on literature and bench scale evaluation of conventional electrorefining and 
electrowinning processes, the possibility of introducing a solvent extraction step for technetium and uranium removal appears feasible. It may also be possible to perform pilot tests using available, uranium-contaminated equipment.

A literature survey indicates the possibility of combining treatment of two wastes, enriched uranium contaminated alkali metal fluorides (Y-12 Plant) and uranium contaminated aluminum compressor blades (Oak Ridge Gaseous Diffusion Plant). The combined treatment of these wastes will concentrate uranium into a relatively small volume and is likely to permit recycle of the specialty aluminum alloy into new compressor blades. It may also be possible to select blades to permit selective recovery of enriched uranium.

During development of processes for removal of mercury from lithium legacy wastes, we reviewed the status of lithium isotope separations equipment. The COLEX, or COLumn EXtraction, process separated lithium isotopes by countercurrent partition between a lithium amalgam and lithium hydroxide solution. Although the bulk of the mercury has been removed from ancillary equipment, the columns and internals, still in place, contain subtantial amounts of surface and sorbed liquid mercury. In conventional decomissioning practice, these would be opened and the internals removed. Preliminary calculations indicate the possibility of physical separation of the bulk of the mercury before the columns are opened. This would greatly simplify decontamination of the old COLEX buildings because it would decrease personal protection and waste production. Similar approaches could be used to decontaminate mercury-soaked carbon and other COLEX legacy wastes.

A number of smaller or lower-research projects are also attractive. Some of them have DOE-wide applicability. For example, sodium nitrate is a major, if not the major, constituent of most mixed low-level tank wastes. Based on a combination of Bureau of Mines technology development reports, industrial process data, and bench verification performed by other DOE sites, it appears that sodium nitrate can be purified by multistep recrystallization. Although it would have to be verified for individual tanks or tank groups which have common constituents, the process could be implemented in an automated unit and would substantially decrease the amount of legacy tank waste.

Although efficiency in the aluminum nitrate crystallization process was increased four-fold by our optimization, the process remains the largest source of Oak Ridge solid mixed process wastes. Although biodenitrification would be possible, we feel that a combination of crystal washing, re-extraction, and selective precipitation has the potential to minimize waste volume.

Other areas which appear promising, based on earlier work by our group, include development of a fixed film process for denitrification of low-concentration, low-dissolvedsolids liquid waste streams at the Y-12 Plant and development of a complete-recycle scrubbing process with controls tied to the electrolysis for the lithium production area. We've either completed bench studies in these areas or feel that small bench research efforts, in conjunction with engineering development, are required. The lithium process could use a decomposition catalyst for which we received a number of national awards, including an RD-100.

As a group, the proposed studies could lead to processes which remove the highest-volume heavily mercury-contaminated metal scrap, eliminate four of the largest uranium. contaminated metal/salt wastes, and greatly decrease the volume of Oak Ridge/DOE legacy waste. 


\section{Volumetrically-Contaminated Nickel Scrap}

\section{Background}

Because of high resistance to fluorides, nickel was used extensively throughout gaseous diffusion plants for production of enriched uranium. As diffusion plant technology is being displaced, nickel and nickel alloy scrap from these plants represents a significant domestic strategic metal resource. A 6,000 ton stockpile, which consists of large, $>99 \%$ pure nickel ingots, is available at Paducah. This material has been well characterized, and its disposition has been reviewed in environmental impact statements. The major contaminants in this material are roughly $1 \mathrm{ppm}$ technetium and $1-10 \mathrm{ppm} \mathrm{U}$ and its daughter products (Department of Energy 1995).

As a result of earlier bench studies supported by EM-50, our working group has identified several effective methods for treating this waste (Compere, et al., 1994, Brown, et al., 1996). Our proposed method involves reoptimizing the current electrowinning process used for commercial nickel production in the Falconbridge Nikkelverk at Kristiansand, Norway (Stenaholt and coworkers 1986a, 1986b, 1988). This process has a solvent extraction step to remove cobalt and the extractant has been successfully used in some systems for uranium and technetium extraction. There is a good possibility that treated nickel would meet European de minimus standards for commercial use. Engineering studies indicate that treatment would be cost-effective, although the varying price of nickel makes commercial metal sales difficult to predict.

\section{Proposed Research}

Bench studies which indicated the feasibility of using a nickel chloride electrowinning process to plate nickel metal have been completed with support from DOE EM-50. The studies indicated high plating efficiency and good quality plates in $1 \mathrm{~cm}^{2}$ samples.

Literature research indicated that the triisooctylamine solvent used to extract cobalt from nickel in commercial electrowinning applications had been successfully used as an extractant for both uranium and technetium. Preliminary shake tests indicated good liquid flow and separation characteristics. However, this extractant has only been reported to separate uranium and technetium from acidic sulfate or nitrate electrolytes. A series of bench tests would have to be performed to evaluate optimum conditions for extraction and recovery of uranium and technetium. Several process alternatives, including a new pertechnate-specific ion exchange resin, will also be evaluated to permit selection of the best process conditions.

Engineering scaleup issues can be addressed using increasingly large commercial pilot electrowinning cells. Additionally, bench and pilot work evaluating size reduction and dissolution alternatives for the nickel metal itself need to be addressed; the commercial process starts with a nickel sulfide matte which is finely divided and readily dissolved with wet chlorine. Solid nickel ingots are harder to dissolve and may need to be shot cast and electrolytically dissolved.

Long-term pilot tests (to resolve any materials compatibility issues; check on buildup of precipitates, such as oxalates or uranium oxides, and verify process mass and energy balances) might be arranged at the old Y-12 Plant electroplating shop. This area, which 
was used to plate uranium parts, is already contaminated. Use of this existing facility would result in a considerable savings of time and money.

\section{Opportunity}

Several attempts to interest a commercial partner in decontaminating this nickel for commercial sale have failed. This has been due to changes in the price of nickel; to changes in the management, operations, and priorities of the companies proposing to recover the nickel; and to the absence of a U.S. de minimus standard for radioactive content of the nickel.

Our preliminary calculations indicate that a facility which recovered diffusion plant nickel would, as a waste disposal process, be cost effective. Several schemes for toll processing of nickel for reuse in DOE applications, such as ultimate waste disposal containers, also appear to be cost effective. The 6,000 tons of volumetrically contaminated nickel, roughly $10 \%$ of the total "nearly pure" nickel in diffusion plants (National Research Council 1996), could serve as a pilot or semiworks for recovery of the larger DOE stockpile of this strategic metal. A small facility at Oak Ridge ( 2 acre) could, in a one or two decade period, reprocess 60,000 tons of nickel, which is equivalent to 1-1/2 years of total U: S. nickel consumption. 


\section{Combined Processing of Aluminum Compressor Blades and Alkali Metal Fluorides}

\section{Background}

Two wastes, 1 to 2 million pounds of aluminum compressor blades from the Oak Ridge Gaseous Diffusion Plant (ORGDP) cascade and more than 100,000 pounds of alkali metal fluorides from Y-12 Plant uranium reduction, could be coprocessed to produce decontaminated aluminum alloy and to economically recover enriched uranium values.

Aluminum, primarily from compressor systems used to circulate uranium hexafluoride through separation system, is a major gaseous diffusion plant waste (National Research Council 1996). The compressors used in U.S. diffusion plants have individual aluminum compressor blades mounted on a heavy aluminum rotor. The compressor blades are die cast from a special aluminum alloy, 214-X, which has been optimized for mechanical properties and long life. Blades are periodically replaced either as a part of routine plant improvements or because of failure (Benton 1953). Although die casting was an economic process for production of the many different types of compressor blades required for the different sizes of compressors, it introduced surface-connected voids into the blades, typically near the base. During operation, these voids filled with uranyl fluoride, bringing the uranium concentration in the blades to roughly $0.3 \%$.

Several different approaches to handling contaminated compressor blades were developed across the last half century. Two of the methods, if combined, have the potential for costeffective waste recovery. The first of these, a method for fluxing molten aluminum 214-X, skimming or draining uranium, and recasting the partially-decontaminated alloy into more compressor blades (Johnston and Penry 1959) has been successfully used by both the Oak Ridge and Paducah Gaseous Diffusion Plants (Lay and Taylor 1958). Because the fluxes used in the 1950s removed only part of the uranium, a standard for blade casting metal which permitted up to $0.3 \%$ uranium in the alloy was established.

A new research separation, which uses modern fluxes, such as calcium fluoride, magnesium fluoride, or cryolite, is reported to permit removal of better than $99 \%$ of uranium from small, pure aluminum samples (Heshmatpour and Copeland 1981a and b; Heshmatpour, Copeland, and Heestand, 1981 and 1983).

A process which combined the phase separation technologies of the 1950 s with highefficiency fluxes could provide cost-effective decontamination of volumetrically contaminated aluminum. A portion of the recovered material could be recycled to supply blades for current diffusion plant use.

The Y-12 Plant has stored substantial quantities of the alkali metal fluoride residue produced during the metallothermic reduction of uranium tetrafluoride. This material is primarily magnesium and calcium fluorides with small amounts of enriched uranium. Because of its enriched uranium content, this material has been stored, rather than discarded. Dilution of the enrichment would facilitate disposal of the alkali metal fluoride.

With process optimization and careful control of process geometry, it is likely to be possible to combine and melt these two wastes to produce clean aluminum alloy (which can be used 
to replace the new material being purchased for blades at Paducah and Portsmouth) and to recover uranium with enrichment levels high enough to be economic.

\section{Proposed Research}

We propose to extend Heshmatpour's bench studies of uranium separation from pure aluminum to the alloy, aluminum 214-X, used for die casting compressor blades. The processing conditions for aluminum 214-X will need to be evaluated to permit selection of appropriate operating conditions. Processed alloy will need to be recast and evaluated, in terms of composition, casting properties, and mechanical properties, to ensure that it will meet specifications for reuse. It is expected that we will work closely with the Paducah and Portsmouth technical staffs to ensure that the resulting material meets their needs.

Although the uranium recovered from blades can be disposed in the alkali metal slag, it could be removed from the slag and the slag recycled. We propose to evaluate physical and chemical methods for uranium separation from the slag.

Separation of blades which contain better-than-native enrichments of uranium is expected to be a mechanical separation based on blade size. Compressor (and blade) sizes typically decrease as uranium enrichment increases because diffusion plants operate as a tapered cascade. Surface-decontamination of blades prior to storage is expected to simplify the separation process. The enriched uranium in even 500 tons of spent compressor blades has considerable value. However, blades with enriched uranium will have to be processed using appropriate geometric design and batch controls.

\section{Opportunities}

If we are able to develop a viable technology, there are several different types of opportunities involved in and growing out of the proposed research project. We've located facilities in the Materials Accountability Area which might be an appropriate processing area for enriched uranium. This would substantially simplify construction and management of any recycle and recovery efforts.

Recycle of the special blade alloy for production of new blades would result in considerable raw materials savings for reblading campaigns. Also, new technologies for pressure casting and parallel supercomputer casting simulation have lead to the production of "defect and void free" complex cast aluminum parts. This technology could improve quality of blades for Paducah and Portsmouth. Project industrial partners are interested in working with Oak Ridge to test small commercial pressure casting systems and compressor blade pressure casting is a good starting point.

The 500 to 1000 tons of blades at ORGDP could lead to opportunities for processing the other 21,000 tons of aluminum in existing diffusion plants. Much of this material is in the form of compressor blades which could be processed using any developed technology. Discussions with Heshmatpour also indicated the possibility of using recovered aluminum for metallothermic reduction of other, more valuable, diffusion plant metals. 


\section{Removal of Mercury from Lithium Processing Equipment}

\section{Background}

Stable lithium isotopes were separated at the Y-12 Plant for use in the production of thermonuclear weapons. Although several approaches were successfully employed at pilot or larger scale, the COLEX, or COLumn EXtraction, process, which used countercurrent extraction of lithium(6) from lithium hydroxide solution into lithium amalgam, was the most successful. Although most of the mercury has been removed from ancillary equipment, heavily contaminated cascade columns and their internals are still intact. The columns are very large, well sealed, and jacketed. The process building, currently in standby but staffed, still has steam and other utilities. A successful waste removal program, for which we provided bench research services, has made the building accessible by removing and treating tank wastes, removing ancillary equipment, drumming wastes which contained a high level of mercury, and cleaning and painting the building. Although many of the waste materials are lightly surface contaminated, a few materials, such as amalgam decomposers, columns, and internals, still contain high levels of mercury.

In addition to research in support of legacy waste treatment, we cocurrently evaluated lithium isotope separations process technologies (Compere and Griffith 1996 and 1997). While we were documenting process technologies, we also developed a list of areas where bench research could significantly improve management of legacy process wastes and equipment.

Two different wastes seemed to offer the best reward for a research and development effort. The columns, with their internals, are difficult to decontaminate because, over decades, mercury is likely to have penetrated into the steel column shell, supports, and internals. The columns are still sealed, but opening them to remove their contents will probably require employees to work in protective clothing with air supplies and may substantially increase the airborne mercury concentration in the building even if the current high-flow ventilation systems are operated. The 50 tons of carbon shapes which were used for phase separation are currently drummed. Treatment of both legacy wastes to remove mercury would significantly improve the ease with which the building can be rehabilitated or decontaminated and decommissioned.

\section{Proposed Research and Development}

It is likely that a significant reduction of the amount of mercury in both wastes could be effected if the columns could be heated under a vacuum with a "cold finger" device for collection of mercury vapors. Because the columns remain sealed and the jacket piping appears to be intact, this may be feasible. Thermodynamic calculations indicate that it may be possible. A combination of bench research and simulation (to evaluate effect of vacuum, actual removal rates, response to temperature, and mechanical properties changes in the metals), coupled with mechanical inspection of the system and estimation of any necessary replacements and upgrades, should indicate if the process is feasible. In addition to questions of rate, the amount of mercury in vacuum-stable salts, such as carbonates, oxides, or sulfides, is also critical because these materials will not be removed 
by vacuum distillation. If bench tests are promising, evaluations at increasing scale will be conducted.

Even if "contained recovery" of mercury from the COLEX columns is not feasible, it may be possible to decontaminate the carbon shapes by retorting.

\section{Opportunities}

We've worked with the staff in this building through our last set of pilots and they're skilled, hard working, and cooperative. Cleaning up the two really high mercury wastes currently sealed in columns and drums would facilitate return of the building to active use, significantly reduce cleanup costs, and reduce the risks of a large-scale mercury spill. It would also greatly decrease the costs of decontaminating and decommissioning other areas of the building because the columns will remain "contained" while they're being stripped of mercury. This is significant because decontaminating a very large building with heavy equipment containing hazardous materials is expensive and difficult under normal conditions. If work has to be performed in protective clothing and self-contained ventilation equipment, the decontamination and decommissioning of the building will become much more difficult and expensive. 


\section{Fixed-Film Biodenitrification of Low-Concentration, Low-Dissolved-Solids Y-12 Plant Streams}

\section{Background}

The Y-12 Plant has historically produced wastes containing very high levels of nitrate $(>10,000 \mathrm{ppm}$ as $\mathrm{N})$. In the past, these wastes often contained high levels of aluminum or calcium, resulting in the production of high levels of solids due to the increase in $\mathrm{pH}$ during biodenitrification. Solids production was increased by use of lime for process neutralization. Recently, increases in recycle of aluminum nitrate nonahydrate (Griffith and coworkers 1991) and minimization of lime neutralization during biodenitrification have eliminated a large fraction of the solids formed at the West End Treatment Facility. Additionally, changes in plant management practices, such as collection of wash waters and rain accumulating in dyked areas, has increased the need to treat relatively high volume, dilute wastes, which are produced at high levels during the spring and summer.

The current tank biodenitrification process, although well suited to the treatment of highconcentration, high-solids wastes, takes weeks to months to complete treatment. It should be supplemented by a high-throughput fixed-film system, like a rotating biological contactor, for rapid treatment of relatively dilute wastes which have a low solids. These systems could effectively remove both nitrate and waste organics from dilute streams and would also substantially reduce both biological oxygen demand (BOD) and chemical oxygen demand (COD) of the waste. A system for use on Y-12 waste would be likely to contain both aerobic and anaerobic sections and would need provision for recycle of a portion of the stream. This would be particularly effective for use in non-RCRA, non-RAD applications.

\section{Proposed Research and Development}

We need to determine probable average and peak loads, based on waste receipt records from previous years. To the extent that planning information is available, we will adjust the data for projected changes in nitrate processing. We will also, using a combination of these data and the working experience of West End Treatment Facility staff, estimate the fluctuations, as well as the need for a "head tanks" or recycle system.

Using standard enrichment techniques, we will then develop and customize a culture for the proposed rotating biological contactor system. Using lab-scale rotating biological contactors, system performance will be optimized. Response of the system to sudden changes in loading will be evaluated. Available Y-12 Plant wastes, such as oils or ethylene glycol, will be evaluated as carbon sources.

Particular attention will be paid to alternation of oxidizing and reducing sections to facilitate stepwise breakdown of complex organic compounds and conversion of reduced nitrogen compounds to nitrate and, ultimately, to nitrogen gas. Although few alternating systems have been used for simple biodenitrification, they have been used successfully in many systems for treatment of high-ammonia wastes that are successively nitrified and denitrified.

After scaleup tests are complete, the system will be scaled up in conjunction with a selected manufacturer and installed at the Y-12 West End Treatment Facility. 


\section{Opportunity}

Availability of a small, fixed film systems would permit the Y-12 Plant West End

Treatment Facility to cope with peak summer loads of dilute, high-volume wastes. The systems are relatively simple to operate and small enough that the units could be stored if they were not used during the winter. Although alternating oxidation/reduction units are relatively uncommon, the technology has been demonstrated for concentrated industrial wastes. Rotating biological contactors are low-energy and can be disassembled and cleaned if there is a substantial amount of solids buildup. If housed in a heated building, the system could be used during the winter. 


\title{
6. Development of a Complete-Recycle Scrubbing Process for Lithium Chloride Electrolysis Offgas
}

\begin{abstract}
Background
Lithium metal is produced at the Y-12 Plant by electrolysis of lithium chloride. Chlorine gas produced by electrolysis cells is piped to $10 \%$ sodium hydroxide scrubbers where it is removed as a mixture of sodium hypochlorite and sodium chloride. The bulk of this material is currently analyzed, packed, and shipped to other sites for use in effluent chlorination. However, the analysis, shipping, and handling costs, coupled with the costs of treating off-specification batches of this highly alkaline hypochlorite, impose a significant financial and time cost on lithium production operations.

Earlier studies on the catalytic degradation of hypochlorite, directed toward treating offspecification batches or managing transportation shortages, indicated the feasibility of using lithium hydroxide in the pre-scrubber, converting it to lithium hypochlorite to recycle the chlorine close to the cell, and catalytically decomposing the material to lithium chloride for drying and recycle. This could eliminate the sodium hypochlorite waste stream with its attendant cost and nuisance and the hydrochloric acid used to convert the lithium hydroxide to chloride. (Compere and coworkers 1987, 1990). The use of the water batch scrubbers already installed or the installation of smaller scrubbers adjacent to individual electrolysis cells would also minimize the transport of chlorine gas to the central final scrubber. This could improve safety by minimizing the possibility of a chlorine leak.
\end{abstract}

We've been discussing this idea with the building management and engineering staffs and have looked at options required to fit this process technology into their current equipment upgrades. The original catalytic decomposition research was directed toward assessment of optimum composition of a mono- or bimetallic catalyst for short-term use in converting high concentrations of sodium hypochlorite in highly alkaline solutions to oxygen gas and sodium chloride. We determined that the optimal bimetallic composition was very close to that of relatively inexpensive conventional alumina-supported cobalt-molybdenum refinery catalysts. If, however, the catalyst will be used for extended periods in lower concentration lithium solutions, some reoptimization for longer life (probably a change in catalyst support composition) will be required. It may also be possible to improve performance by optimizing a three-metal catalyst system. It may also be possible to use a nickel-based catalyst marketed for use in chlor-alkali production streams.

\section{Proposed Research and Development}

We propose to evaluate systems for the removal and recycle of chlorine from lithium chloride electrolysis using smatl lithium hydroxide scrubbers which serve individual electrolysis cells. Because the optimum cobalt molybdenum ratio is one commonly used in a variety of commercial catalysts, we would propose to screen these materials for service life and for diffusion of catalytic materials into the process stream first. If service life and breakdown are unsatisfactory, then new catalyst compositions on substrates known to be resistant to degradation by lithium hydroxide and hypochlorite, such as chemical stoneware, could be prepared and evaluated. 
It may also be possible to use the current in present electrolysis cell to control addition of lithium hydroxide to the scrubbing system. This would minimize chemical use and improve recycle of lithium chloride.

During the project, we will work closely with building staff to control any difficulties that could arise from inclusion of catalyst breakdown products in a recycle chemical stream. If necessary, we will evaluate appropriate methods, such as filtration, for controlling these materials.

The proposed studies include an engineering analysis of costs and design of test equipment. Engineering group members would be involved in the design and installation of the new equipment. However, we've already explored this with the Special Materials Organization and a Pollution Prevention Assessment has been prepared. If the research leads to successful development, it is likely that the cost of process equipment modifications will range between $\$ 300,000$ and $\$ 400,000$ (Special Materials Organization, et al, 1997).

\section{Opportunities}

This project has several advantages. By decreasing the possibility of chlorine gas escape, it would improve the safety of humans and plant equipment. It would decrease or eliminate the need to handle, ship, and dispose of highly alkaline sodium hypochlorite solutions, rated as one of the Y.12 Plant's more hazardous wastes. It also minimizes the need to store and dispose of alkaline sodium hypochlorite solutions which cannot be shipped due to solution contaminants or transportation interruptions. 


\title{
7. Maximizing Recycle of Nitrates from Extraction Raffinates
}

\author{
Background
}

Aluminum nitrate nonahydrate is recovered from uranium extraction raffinates by crystallization. Prior to 1990 , the efficiency for aluminum nitrate recovery was only 20 $25 \%$ because the mother liquor was not recrystallized. The unrecovered aluminum nitrate became waste that produced several million pounds of mixed waste sludge during biodenitrification. Several million gallons of this material are now stored in a tank farm at the west end of the Y-12 site. Analysis of these mixed waste sludges revealed that over $90 \%$ of the entire Y-12 Plant sludge was attributable to acid aluminum nitrate raffinates.

As a result of an earlier study, operators began recrystallizing and recycling aluminum nitrate mother liquor (Griffith and coworkers 1991). The process received a DOE Oak Ridge Operations Office Annual Waste Minimization award and a number of internal awards. No substantial buildup of uranium has been noted in the tanks of the facility, aluminum nitrate recovery improved to $80-90+\%$, and aluminum nitrate purity remained at acceptable levels.

After recycling the mother liquor a few times through the crystallizer, the build up of contaminants prevents future crystallization of aluminum nitrate. At this point, mother liquor from the crystallizer must be disposed and sent to biodenitrification. Although the recrystallization process was extremely effective in reducing the overall volume of Y-12 Plant mixed-waste, spent aluminum nitrate raffinate remains a major contributor to mixed-waste sludges and is expected to increase as enriched uranium processing restarts and increases.

Operation of a dedicated biodenitrification is periodically proposed as an alternative to sending aluminum nitrate wastes to the West End Treatment Facility. A dedicated facility was operated successfully in previous years. However, repairs have been estimated to exceed the costs of a new dedicated biodenitrification facility. Although biodenitrification is possible, it would produce substantial amounts of mixed-waste sludge and operation would be complicated by the periodic batch release of "non-crystallizable" aluminum nitrate raffinate or mother liquor. Since several months can elapse between these releases, continuous operation of a biological system would be difficult and a "fullrestart" would probably be required each time the biological system was used.

Our investigations indicate that several features of the acid nitrate system could be exploited to improve nitrate recycle and purity with very limited capital equipment expenditures. Acid aluminum nitrate raffinate typically contains calcium. The system precipitates relatively pure aluminum nitrate nonahydrate until it reaches an invariant point. After this, calcium can be removed and the mother liquor volume made up with fresh aluminum nitrate. Because trace impurities, such as chromium salts, concentrate on the surfaces of aluminum nitrate crystals, it is possible to remove these materials by separately collecting water used to wash crystals during centrifugation. Trace elements can be selectively precipitated from collected centrifuge wash water and removed by filtration.

Changes in disposal practices and in ancillary processes, such as nitric acid recycle, could be used selectively to decrease trace element levels in aluminum nitrate raffinate. For 
example, steam stripping during nitric acid distillation and recycle could be used to remove a number of trace metals, including titanium zirconium, silica, and iron. To decrease the amount of enriched uranium sent to the West End Treatment Facility, uranium could be recovered from spent raffinate by conventional dibutyl carbitol extraction. Depending on the level of removal desired, carbitol in the form of microdroplets could be stripped from the system by centrifugation or ultrafiltration.

\section{Proposed Research}

Two different issues need to be addressed: increasing the purity and recycle of aluminum nitrate and decreasing the amount of uranium sent to the West End Treatment Facility. Recycle is limited by the ability to produce acceptable aluminum nitrate crystals. Based on earlier studies, trivalent metals such as chromium and iron, which precipitate with aluminum nitrate, are the most difficult trace contaminants to remove (Griffith and coworkers 1991). Alkali metal impurities, such as calcium, and, to a lesser extent, magnesium and lithium, are present in raffinates at higher levels. Bench studies are needed to determine when to cease recycling a given batch of aluminum nitrate and how best to control or remove trace and alkali metals so that aluminum nitrate can be recycled.

A brief examination of the quality of aluminum nitrate feedstocks, alumina, and nitric acid should be made to determine whether it would be possible or cost-effective to purchase alumina or nitric acid with lower levels of contaminants. This would decrease the amounts of iron and chromium in aluminum nitrate and could, thereby, increase recycle. Similarly, restriction of leaching of trace materials, such as iron and chromium, from process equipment should also be considered. It may be possible to decrease these materials substantially by substitution of more corrosion resistant process vessel materials during routine upgrades and replacements.

Selective precipitation and electrodeposition processing will also be evaluated using a combination of literature survey, bench tests, and simulation with the goal of developing simple, batch trace element removal processes which can be scaled from single drum to ten thousand gallon tank lots of spent raffinate. Precipitation of both the waters used to wash crystals during centrifugation spent crystallization liquor will be evaluated.

Strategies for selectively precipitating calcium or calcium nitrate will also be evaluated. Calcium is, at present, the major bulk contaminant in aluminum nitrate raffinates. Although the number of cations in the system complicate analysis, in a "pure" aluminum nitrate - calcium nitrate system, there is an invariant point. The predominant cation precipitates as nitrate until the invariant point is approached. Strategies for selectively precipitating calcium salts, including nitrate, without removing aluminum, will be discussed.

Reoptimization of aluminum nitrate precipitation from spent crystallization liquor, by increasing operating temperature, decreasing operating pressure of the crystallizer, or changing the composition of the stream, will also be considered. The reoptimized operating conditions would be used only for recovery of spent liquors.

\section{Opportunity}

This research, although on a small part of a small system, would substantially decrease the amount of mixed waste sludge produced by the Y-12 Plant as a whole. Although the 
stream is small at present, the volume will increase as enriched uranium processing resumes.

In the past, high levels of spent aluminum nitrate raffinate formed solid, abrasive sludges which damage equipment. As mixed waste, these sludges represent a substantial disposal cost to the Y-12 Plant.

Although earlier studies provided the basis for substantial improvements in raffinate recycle, they indicated the likelihood for being able to achieve much higher levels of recycle, and, thereby, a substantial decrease in plantwide mixed waste production, with simple, cost-effective process technologies. 


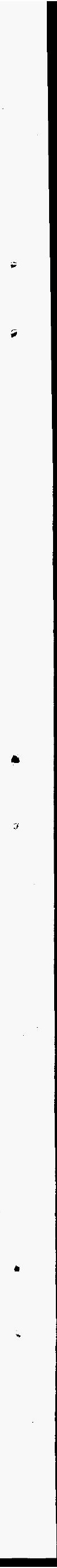




\section{References}

Benton, S. T. 1953. Uranium found in blades of a $K-31$ compressor. ORGDP report KLI-2043.

Brown, G. M.; Compere, A. L.; Griffith, W. L; Hayden, H. W.; and Wilson, D. F. 1996. Preliminary evaluation of electrowinning for nickel scrap recovery. ORNL/TM-13019.

Compere, A. L., and Griffith, W. L. 1987. Catalytic sodium hypochlorite degradation using a kynar stabilized catalyst. Oak Ridge National Laboratory report ORNL/TM-10471.

Compere, A. L., and W. L. Griffith. 1996. Lithium isotope separation facilities, plants and equipment (Harmonized tariff numbers 8401.20, 8413.50, 8413.60, 8413.70, 8413.81, 8413.91, 8419.39, and 8543.30). In A handbook for the nuclear suppliers group dual-use annex, Section 8.8, pp. 8-47 - 8-52. Los Alamos manual LA-13131-M.

Compere, A. L., and W. L. Griffith. 1997. Lithium isotope enrichment. A volume of the Einstein Encyclopedia. Washington DC: Defense Intelligence Agency.

Compere, A. L.; Griffith, W. L.; and Huxtable, W. P. 1990. Process for degrading hypochlorite and sodium hypochlorite. U.S. patent 4,963,341.

Compere, A. L.; Griffith, W. L; Hayden, H. W.; and Wilson, D. F. 1996. Decontamination and reuse of ORGDP aluminum scrap. ORNL/TM-13162.

Compere, A. L.; Griffith, W. L; Hayden, H. W.; Johnson, J. S., Jr.; and Wilson, D. F. 1994. Contaminated nickel scrap processing. ORNL/TM-12900.

Department of Energy. 1995. Proposed sale of radioactively contaminated nickel ingots located at the Paducah Gaseous Diffusion Plant, Paducah, Kentucky. DOE draft environmental assessment DOE/EA-0994.

Griffith, W. L.; Compere, A. L.; Googin, J. M.; and Huxtable, W. P. 1991. Aluminum nitrate recrystallization and recovery from liquid extraction raffinates. Oak Ridge National Laboratory report ORNL/TM-11471.

Griffith, W. L.; Compere, A. L.; Googin, J. M.; and Huxtable. W. P. 1992. Reducing emissions from uranium dissolving. Oak Ridge National Laboratory report ORNL/TM-12211.

Heshmatpour, B., and G. L Copeland. 1981a. Disintegration of liquid metals by low pressure water blasting. International Journal of Powder Metallurgy \& Powder Technology 17(3): 213-220.

Heshmatpour, B., and G. L Copeland. 1981b. Metallurgical aspects of waste metal decontamination by melt refining. Nuclear and Chemical Waste Management 2: 25-31.

Heshmatpour, B.; Copeland, G. L.; and Heestand, R. L. 1981. Granulation of slags and metals after melt refining of contaminated metallic wastes. Nuclear and Chemical Waste Management 2: 3337.

Heshmatpour, B.; Copeland, G. L.; and Heestand, R. L. 1983. Decontamination of transuranic contaminated metals by melt refining. Nuclear and Chemical Waste Management 4: 129-134.

Huxtable, W. P.; Compere, A. L.; Griffith, W. L.; and Googin, J. M. 1993. Process waste minimization opportunities at the Y-12 Plant. Martin Marietta Energy Systems report Y/EN4841.

Johnston, R. A., and B. D. Penry. 1959. Reprocessing scrap aluminum alloy compressor blades. PGDP report KYM-16.

Lay, C. R., and E. R. Taylor. 1958. Compressor blading: fatigue strength of reclaimed 214-X aluminum alloy. ORGDP report KL-316.

National Research Council. 1996. Affordable cleanup? Opportunities for cost reduction in the decontamination and decommissioning of the nation's uranium enrichment facilities. Washington D.C.: National Academy Press. 
Special Materials Organization, Cengral Engineering Services, and the Y-12 Pollution Prevention Office. 1997. Y-12 Plant lithium metal production process level II pollution prevention opportunity assessment. Lockheed Martin Energy Systems report Y/WM-341, Revision 1.

Stensholt, E. O.; Zachariasen, H.; and Lund, J. H. 1986a. Falconbridge chlorine leach process. Transactions of the Institute of Mining and Metallurgy, Section C: C10-C16.

Stensholt, E. O.; Zachariasen, H.; and Lund, J. H. 1986b. The Falconbridge chlorine leach process. In Nickel Metallurgy Symposium, Proceedings of the 25th annual conference on metallurgy, vol. 1, ed. Ozberk, E., and S. W. Marcuson, pp. 442-463. Canadian Institute of Mining and Metallurgy: Montreal, Quebec.

Stensholt, E. O.; Zachariasen, H.; Lund, J. H.; and Thornhill, P. G. 1988. Recent improvements in the Falconbridge nickel refinery. In Extractive metallurgy of nickel and cobalt, ed. G. P. Tyler and C. A. Landholt. London: The Metallurgical Society. 


\section{INTERNAL DISTRIBUTION}

1-2. Central Research Library

3-4. Laboratory Records Department

5. Laboratory Records, ORNL-RC

6. ORNL Patent Section

7-9. M\&C Records Office

10-14. A. L. Compere

15. D. F. Craig

16. J. R. Distefano

17-21. W. L. Griffith
22-26. H. W. Hayden
27-31. W. P. Huxtable
32. N. C. Jessen, Jr.
33. J. S. Johnson, Jr.
34. O. W. Muenzer
35. S. E. Poligone
36. M. L. Poutsma
37. A. W. Smith
38-42. D. F. Wilson

\section{EXTERNAL DISTRIBUTION}

43. E. G. Cumesty; ORNL Site Manager; Department of Energy; Oak Ridge National Laboratory; Post Office Box 2008; Oak Ridge, Tennessee 37831-6269

44. I. W. Jeter, Bechtel Jacobs Company LLC, Building K-1037, MS 7357, East Tennessee Technology Park; Oak Ridge, TN 37831-7357.

45. G. L. McAllister, Bechtel Technology and Consulting, 50 Beale St., P. O. Box 19395, San Francisco CA 94119-3965.

46. E. W. McDaniel, 724 Robertsville Rd., Oak Ridge TN 37830.

47. Hank McGuire; Vice President, Government Programs; Foster Wheeler Environmental Corp.;111 Union Valley Road; Oak Ridge TN 37830

48. R. W. Meehan, Oak Ridge Operations, Box 2001, Oak Ridge TN 37831.

49. J. F. Nemec, Bechtel Jacobs Company LLC, Building K1001, MS 7171, East Tennessee Technology Park, Oak Ridge, TN 37831.

50. R. T. Taussig, Bechtel Technology and Consulting, 50 Beale St., P. O. Box 19395, San Francisco CA 94119-3965.

51-52. DOE Office of Scientific and Technical Information, P. O. Box 62, Oak Ridge TN 37831.

For distribution by microfiche as shown in DOE/OSTI-4500R75, Distribution Category UC-902 